\title{
EFFECT OF TAX DEBT ON PARTICIPATION TO PUBLIC PROCUREMENTS
}

\author{
Yeliz Neslihan AKIN ${ }^{1}$
}

\author{
Salim Ateş OKTAR ${ }^{2}$
}

\begin{abstract}
In terms of public procurement, the finalised tax debt has been regulated as a barrier of participation to tenders only in Public Procurement Law no. 4734. The authority to determine the type and amount of finalised tax debt regulated as a proficiency criteria as well, has been given to the Public Procurement Authority with the Law No. 4734. While the Public Procurement Authority uses this legal authority, must obtain appropriate opinion of Revenue Administration. The finalised social security premium debt also has been regulated as a barrier of participation to tenders in Law no. 4734, therefore it is considered that the legislator had the intendment to point out the scope of the tax in a narrow sense with the phrase OF finalised tax debt. According to our opinion, tax loss fines, late fee and interests and charges regulated as types of finalised tax debt in General Notification on Public Procurement aren't not included in the scope of narrow and technical sense of tax debt. For this reason, it is considered that these regulations are contrary to Law no. 4734. In this context, it is recommended to change as a finalised receivable or overdue debt the phrase of finalised tax debt in Law no. 4734. Additionally, regulating the legal consequences of finalised tax debt in all procurement laws in the public procurement legislation will be more appropriate for equity and desired interest in terms of public budget.
\end{abstract}

Keywords: Public Procurements, Proficiency Criteria, Finalised Tax Debt, Financial Liabilities, General Notification on Public Procurement, Public Procurement Law No. 4734.

JEL Code: H57, K34, K39.

\section{Introduction}

In order to evaluate the bid submitted in the tender conducted with the Public Procurement Law no. 4734, tenderer natural or legal person mustn't have finalised tax debt in accordance with Turkey's or the legislation of their respective countries according to Article 10 of the said Law. Because finalised tax debt has been regulated as a barrier of participation to tender according to the Law no. 4734. Authorization to determine of type and amount of finalised tax debt has been given to Public Procurement Authority with the condition of the appropriate opinion of the Revenue Administration by the Law no. 4734. Pursuant to this authorization, the Public Procurement Authority has made some arrangements in the General Notification on Public Procurement. In this context, within the framework of the doctrine views and judicial decisions on the financial liabilities regulated in Article 73 of the Constitution, the definition of tax in narrow and wide sense has been tried to be reached. It is determined that the the narrow meaning of tax has been used with the phrase of the finalised tax debt stated in the Law no. 4734. Based on this determination, tax loss fines, late fee and interests and charges determined as finalised

\footnotetext{
1 Res. Asst., Istanbul University, Faculty of Economics, Departments of Public Finance, Division of Fiscal Law, akin.yn@istanbul.edu.tr

2 Prof., Istanbul University, Faculty of Economics, Departments of Public Finance, Division of Fiscal Law, oktarat@istanbul.edu.tr
} 
tax debt with the regulations of the General Notification on Public Procurement are considered to be contrary to the provisions of Law no. 4734.

\section{Defining Tax Debt in the Context of Financial Liabilities}

\subsection{Types of Financial Liabilities}

\subsubsection{Tax}

Tax is unrequited (Aksoy, 2010: 5; Aksoy, 2011: 142; Kaneti, 1989: 4; Yılmaz, 2018: 92); is not based on reciprocity (Aksoy, 2010: 3; Musaball, 1978: 9; Oktar, 2019: 4). As a rule, the distinction between tax and non-tax financial liabilities is the aforementioned characteristic. It is stated that the principle of reciprocity and utilization is valid in financial liabilities other than tax (Öncel et al., 2018: 56).

\subsubsection{Non-Tax Financial Liabilities}

It is understood that non-tax financial liabilities were addressed with as a classification that are share of expenditures and other financial liabilities, apart from taxes, charges and duties (Kaneti, 1989: 6-8). Furthermore, it is stated that there are financial liabilities expressed in the form of parafiscal liabilities, share of expenditures and goodwill together with charges and duties in tax equivalents (Oktar, 2019: 5-8; Oktar, 1996/1997: 162-165).

\subsection{Tax Debt}

\subsubsection{Tax Debt in the Narrow Sense}

It is stated that the tax debt represents the amount of concrete and personal tax to be paid by the taxpayer (Neumark, 1951: 68). In the decision of the Constitutional Court, it is indicated that tax in the narrow sense refers to the taxes that everyone is obliged to pay according to their financial power to cover public expenses ${ }^{3}$. These explanations constitute the scope of the tax in the narrow sense.

\subsubsection{Tax Debt in the Wide Sense}

According to an opinion in the doctrine, Turkish tax law covers the charges, duties and share of expenditures besides taxes in the narrow sense (Kaneti, 1989: 9). According to another view, the scope of tax law needs to be considered widely and tax equivalents and regarding penalties should be included in the scope of tax law (Mutluer \& Dayanç, 2014: 14) Finally, it is also stated in the doctrine that the authorization of taxation in the wide sense, includes the authority for all kinds of financial liabilities; in this context, as well as taxes, charges, duties, goodwill and tax equivalents such as allowances and contributions paid to social security institutions and professional associations are covered by this authority (Çağan, 1982: 5).

\footnotetext{
${ }^{3}$ See, Constitutional Court, E. 1984/9, K. 1985/4, February 18, 1985.
} 


\section{Conditions of Participation in Public Tenders}

When the barriers of participation in Article 10 of the Public Procurement Law no. 4734 are examined, although it is seen that the finalised tax debt is one of the elements of the proficiency principle in the tenders to be conducted in accordance with the said Law; in the State Procurement Law no. 2886 and other laws governing public procurement procedures, it is observed that tax debt hasn't been regulated as a barrier of participation to tenders.

\section{Tax Debt in Public Tenders}

\subsection{Types and Amount of Tax Debt in Public Tenders}

According to article 17.4.1. of the General Notification on Public Procurement (GNPP), exceeding 5.000,00 TL and the following are considered as finalised tax debt ${ }^{4}$ :

Annual income tax

Annual corporation tax

Value-added tax

Special consumption tax

Special communication tax

Motor vehicle tax

Tax on games of chance

Stamp Tax

Banking and insurance transactions tax

Withholding and provisional taxes related to income and corporation tax

Charges

Tax loss fines for the regarding receivables mentioned above

Late fee and interests for the regarding receivables mentioned above

\subsection{Characteristics of Tax Debt in Public Tenders}

\subsubsection{Circumstances Accepted as Finalised Tax Debt}

It is seen that in the article 17.4.2. of the GNPP which circumstances will be accepted as a finalised tax debt and not.

\footnotetext{
${ }^{4}$ In article 17.4.1. of the GNPP has been amendments by the Notification of Related to Making Amendment to General Notification on Public Procurement which entered into force on 01.03.2018. With the aforementioned amendments, motor vehicle tax,tax on games of chance, stamp tax and charges were included in the scope of tax debt. See, Official Gazette No. 30324-February 6, 2018.
} 


\subsubsection{Legal Consequences}

As it is stated that the persons who have finalised tax debt will be excluded from the tender conducted within the scope of Law no. 4734, the bids of these tenderers shall not be taken into consideration.

\section{The Issue of Contradiction of General Notification on Public Procurement to the Law No. 4734}

In article 10 of the Law no. 4734, it is seen that the finalised social security premium debt has been also regulated as a barrier of participation to tender. Since the Law no. 4734 includes statement of tax debt together with statement of social security premium debt, it is concluded that the legislator aims to regulate tax in a narrow and technical sense.

\subsection{Tax Loss Fines}

The tax loss fine which has been regulated within the scope of the finalised tax debt in Article 17.4.1. of the GNPP isn't a financial liability specified in Article 73 of the Constitution ${ }^{5}$. For this reason, it is concluded that the regulation related tax loss fine in GNPP is contrary to the Law no. 4734.

\subsection{Late Fee and Interests}

The late fee and interests which has been regulated within the scope of the finalised tax debt in Article 17.4.1. of the GNPP isn't a financial liability specified in Article 73 of the Constitution, as well ${ }^{6}$. For this reason, it is concluded that the regulation related late fee and interests in GNPP are contrary to the Law no. 4734.

\subsection{Charges}

Although the charge is a financial liability specified in Article 73 of the Constitution; it is neither covered by the tax debt in a narrow and technical sense ${ }^{7}$ nor included in tax classification by nature ${ }^{8}$. For this reason, it is concluded that the regulation related charge in GNPP is contrary to the Law no. $4734 .^{9}$

\footnotetext{
5 See, Constitutional Court, E. 2001/3, K. 2005/4, January 6, 2005.

6 See, Constitutional Court, E. 1988/7, K. 1988/27, September 21, 1988.

7 However, in the doctrine, according to the views defending the wide meaning of the tax, the charge is included in the scope of the tax debt.

8 See, Public Procurement Authority-Decision of Incompatibility, No. 2017/UH.I-28, January 1, 2017.

9 In the court case about the amendment made to the article 17.4.1. of GNPP regarding the inclusion of charges in finalised tax debt, it was decided by the 13th Chamber of the Council of State to stop the execution of the phrase of "charges" and thereupon, a decision on Draft About Making Amendment Notification to General Notification on Public Procurementwas taken by the Public Procurement Authority. See, Public Procurement Authority-Decision of Regulatory, No. 2019/DK.D-9, January 1, 2019. Pursuant to the aforementioned decision, it has been announced that the charges shall not be taken into account in the calculation of the tax debt within the scope of Article 17.4.1. of the GNPP and the the proceedings carried out by the administrations shall be established according to the decision of the said Authority. See, Public Procurement Authority, Removing "Fees" from the Extent of Tax Debt, http:// www.ihale.gov.tr/Duyuru/296/vergi_borcu_kapsamindan_\%E2\%80\%9Charclarin\%E2\%80\%9D_cikarilmasi.html.
} 


\section{Conclusion}

Because of the legislator's aim was to regulate the tax in a narrow sense in Law no. 4734, it is considered that the tax loss fines, late fee and interests and charges regulated in the GNPP as a finalised tax debt are contrary to the said Law. In our opinion, the term finalised tax debt in the Law no. 4734 should be changed to finalised public receivables or overdue debts and should include the scope of tax debt in the wide sense.

Tax types for the commercial activities of tenderers such as the annual income tax, annual corporation tax, withholding and provisional taxes related to income and corporation tax, value added tax, special consumption tax, banking and insurance transactions tax, stamp tax and customs tax are must be within the scope of finalised tax debt. However, it is considered that all tax types that can be collected in Turkish tax law should be included in terms of an assessment to be made on the basis of the fact that the acceptance of the tax liability is a citizenship duty and considering tax security.

Finally, the merely law in which finalised tax debt has been regulated as a barrier of participation to tenders is the Law no. 4734. However, this situation is contrary to the equity and the desired interest in terms of public budget. Therefore, it is considered that the legal consequences attributed to the legitimate aim of tax debt should be valid for all public procurement legislation.

\section{References}

Aksoy, Ş. (2010). Tax Law and Turkish Tax System, 6th Edition, İstanbul, Filiz.

Aksoy, Ş. (2011). Public Finance, 4th Edition, İstanbul, Filiz.

Çağan, N. (1982). Taxation Authority, İstanbul, Kazancı.

Kaneti, S. (1989). Tax Law, 2nd Edition, İstanbul, Filiz.

Musaballı, H. (1978). Tax Law and Turkish Tax System, İstanbul, Sadrettin Tosbi No.: 4.

Mutluer, M. K. \& Dayanç, N. N. (2014). Tax Law: General and Special Provisions, 4th Edition, Ankara, Turhan.

Neumark, F. (1951). Enquiries on Public Finance, 4th Edition, İstanbul, İstanbul University Press.

Oktar, S. A. (1996/1997). "Tax-like Financial Liabilities, Additional Financial Liabilities and Analysis of a Totological Regulation", i.U. Faculty of Economics- Finance Research Center Conferences, 37th Series, pp. 155-189.

Oktar, S. A. (2019). Tax Law, 14th Edition, İstanbul, Türkmen.

Öncel, M., Kumrulu, A. \& Çağan N. (2018). Tax Law, 27th Edition, Ankara, Turhan.

Yılmaz, B. E. (2018). Public Finance, 3rd Edition, İstanbul, Der.

Constitutional Court, E. 1984/9, K. 1985/4, February 18, 1985; Official Gazette No. 18793-June 26, 1985. 
Constitutional Court, E. 1988/7, K. 1988/27, September 21, 1988; Official Gazette No. 20031-December 26, 1988.

Constitutional Court, E. 2001/3, K. 2005/4, January 6, 2005; Official Gazette No. 25972-October 20, 2005.

Public Procurement Authority-Decision of Incompatibility, No. 2017/UH.I-28, January 1, 2017.

Public Procurement Authority- Decision of Regulatory, No. 2019/DK.D-9, January 1, 2019.

Public Procurement Authority. Removing "Fees" from the Extent of Tax Debt, http://www. ihale.gov.tr/Duyuru/296/vergi_borcu_kapsamindan_\%E2\%80\%9Charclarin\%E2\%80\%9D_ cikarilmasi.html, (21.01.2018). 